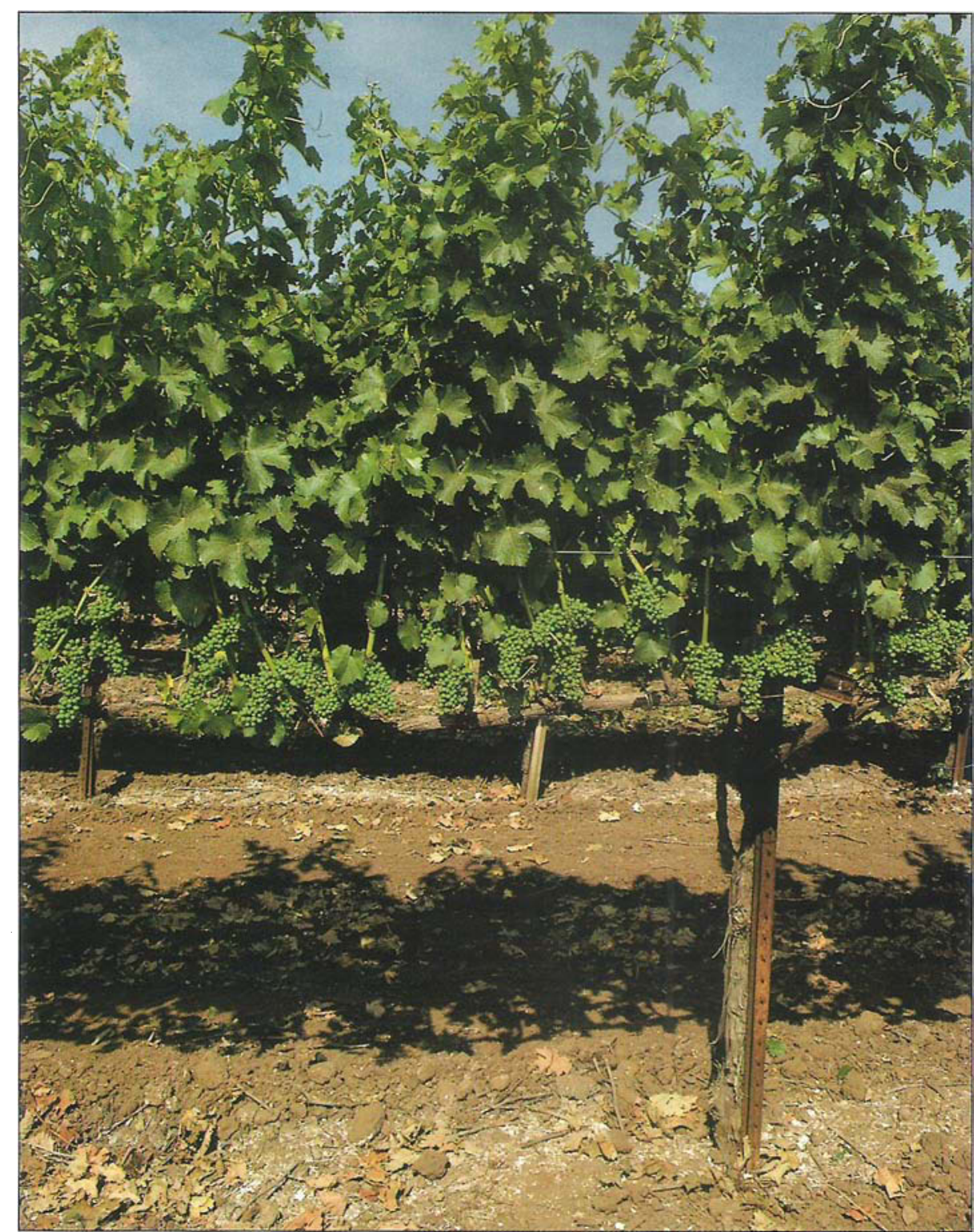

\section{Leaf removal in wine grapes: a case study in extending re- search to the field}

\author{
Robert A. Pence $\square$ James I. Grieshop
}

\section{Leaf removal reduces pesticide use in California wine grapes. This pre- liminary study estimates the extent of that reduction and examines some reasons why leaf removal made the successful transition from applied research to produc- tion-scale field use.}

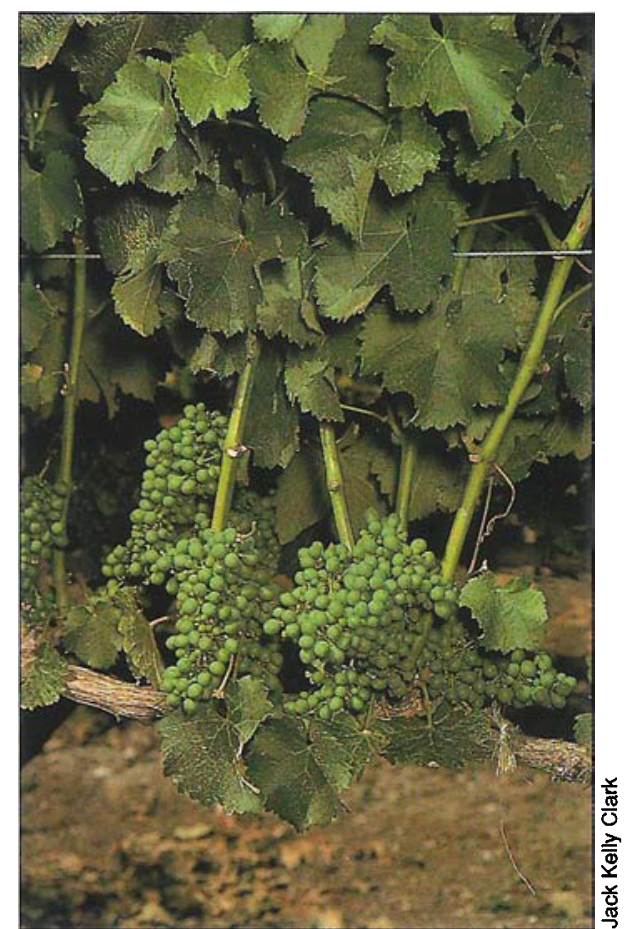

Photographs show winegrape berry clusters exposed through hand leaf removal in a Sonoma County Sauvignon Blanc vineyard.

1990). That evaluation also concluded that selected UCIPM funded projects should be studied in detail to more closely examine evidence of both field use and the impact on pesticide use.

This case study offers a preliminary examination of two UCIPM research projects on the effectiveness of canopy management through leaf removal as a means of $\geq$ pest control in wine grapes. The aim was to provide insight into the extension and implementation decisions that led to the successful translation of this applied research into production-scale field use. The study was designed to address three questions: 1) Are California growers using leafremoval strategies refined by UCIPM research? 2) What factors have contributed to the field implementation of the research-based strategies? 3) What has been the impact of leaf removal on pesticide use?

\section{Canopy management}

Canopy management through leaf removal is a cultural pest control method in which certain leaves are selected and physically removed around fruit clusters after berry set. The procedure is labor intensive, requiring a separate use of vineyard field labor each season. Climatic conditions and pest pressures dictate the extent of leaf removal on each vine. The effect of canopy management by limited removal of foliage is to alter the microcli- 
mate within each vine by creating windows of increased air circulation and light penetration.

In a 3-year UCIPM study initially funded in 1985, UC plant pathologists Jim Marois and Doug Gubler determined that leaf removal substantially reduced the incidence of Botrytis bunch rot, a fungal disease that is a major economic threat to Northern and Central Coast California wine-grape growers. Their research showed that leaf removal created an environment unfavorable to fungus development and altered vine morphology for better resistance to infection (see California Agriculture, March-April 1989). They also found that the environment created by leaf removal permitted better penetration of pesticide sprays onto the grape vines, thereby allowing reduced pesticide application rates. Prior to this research, recommended control for Botrytis consisted of repeated applications of fungicides such as captan and benlate.

Related research showed the benefits of leaf removal extended beyond Botrytis control in coastal growing regions. In a study begun in 1988 by UCIPM Area Advisor Jim Stapleton (with assistance from IPM Area Advisors Bill Barnett, Marois and Gubler), substantial evidence was found that foliage removal lessened the incidence of summer rot complex in San Joaquin Valley vineyards (see California Agriculture, September-October 1990).

Summer or sour rot is a major disease complex affecting many varieties of wine grapes grown in the warmer, interior valleys of California. Harvest losses from summer rot can range from $2 \%$ to complete crop failure. Past UC recommendations for control of summer rot centered on a program of multiple fungicide spray applications.

The San Joaquin Valley study also indicated that early season leaf removal reduced leafhopper populations. When present in large numbers, leafhoppers car: lead to vine defoliation, cosmetiçally damaged fruit and irritation to hand pickers. Previous recommendations for leafhopper control included one to three applications of insecticides such as dimethoate and thiodan each growing season.

These research efforts offered evidence that positive economic and environmental benefits would occur as a result of leaf removal. However, it was unknown if California wine-grape growers were managing canopies through leaf removal, what factors contributed to their adoption of this practice and whether it led to a reduced pesticide use. Consequently, this qualitatively based evaluation was undertaken to provide preliminary evidence addressing these three questions.

\section{Methods}

The two leaf-removal projects were selected for more detailed study because of their potential impacts on in-field pesticide application rates in California vineyards. Area IPM advisors and county farm advisors who worked in wine-grape growing regions of the state were first interviewed about their experiences with the research and dissemination of information on leaf removal. In turn, these advisors identified growers who used leaf removal on a production scale. Eight key growers and three winery viticulturists representing wineries with substantial statewide contract grape acreage were selected for in-depth interviews on the basis of geographic location.

Interviews were conducted at each grower's vineyard during July 1990 . The three major winery representatives were interviewed in person and by telephone during the same period. The 15 informants ( 4 from Cooperative Extension and 11 from the wine industry) were later contacted as needed by telephone to clarify previous interview responses. Through commodity group association, winery contract and CE outreach, these key informants reported direct or indirect knowledge of the management strategies used on approximately $80 \%$ of California's wine-grape acreage. Interviews of project researchers provided detailed information about the decision-making and research processes behind the IPM canopy management studies.

\section{Adoption of canopy management}

Our estimates of statewide acreage under leaf removal were based on identification of grape varieties and geographic regions especially threatened by Botrytis and summer rot fruit diseases. For this estimate, we used only Central Coast, North Coast and San Joaquin Valley acreage planted in Botrytis and summer rot susceptible varieties (fig. 1). These three winegrape growing regions account for $96 \%$ of California wine-grape acreage. Varietal acreage for each region was obtained from the 1989 summary of California grape acreage published by the California Agricultural Statistics Service (table 1).

Extent of leaf removal by acreage was determined through comparison of key informant reports. Growers, IPM Area Advisors, County farm advisors and winery viticulturists from each of the three major growing regions estimated the percentages of regional Botrytis and summer rot susceptible acreage currently under a leafremoval strategy. When key informant estimates were in conflict, the most conservative estimate was used in calculating total acreage under leaf removal.

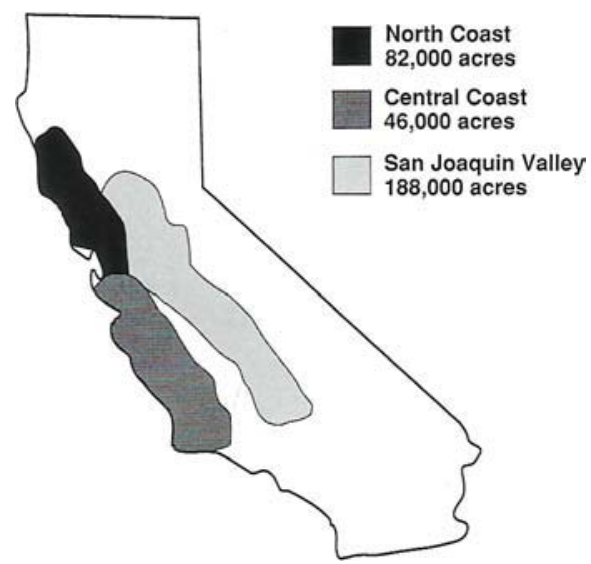

Fig. 1. Major Wine Grape Growing Regions of California, as reported by the California Agricultural Statistics Service' 1989 Summary of California Grape Acreage.

On the basis of key informant reports, we estimated $20 \%$ of Central Coast (e.g., Santa Barbara, San Luis Obispo, Monterey Counties), $50 \%$ of Northern Coast (e.g., Sonoma, Napa, Mendocino Counties) and $10 \%$ of San Joaquin Valley (e.g., Kern, Fresno, Madera, Tulare, San Joaquin, Stanislaus, Yolo Counties) wine-grape acreage was managed under some form of leaf removal. Based on these estimates, since $1989,20 \%(50,900$ out of 243,700 acres) of the statewide acreage planted in Botrytis and summer rot susceptible winegrape varieties has been managed each year using leaf removal.

\section{Diffusion of canopy management}

Efforts by both the wine-grape industry and UC Cooperative Extension personnel have been instrumental in the rapid diffusion and adoption of canopy management on California wine-grape acreage. Farm advisors, IPM area advisors, winery representatives and pest control advisors (PCAs) all played important roles in educating growers and encouraging the use of leaf removal. Due to the economic bonds connecting growers to the wine-grape contract system, some wineries exerted critical influence in ensuring the adoption of this vineyard management strategy. Some major California wine processors, interested in improving wine-grape-flavor, used extensive field trials, recommendations from winery field representatives and commodity contract incentives to encourage leaf removal by their contract growers.

Although winery influence demonstrated the most decisive leverage in encouraging grower trial use of leaf removal, not all wineries had the commitment or resources to employ new research in vineyard management strategies. Through commodity group meetings, personal grower contacts and experimental trial plots, Cooperative Extension farm advi- 
sors played an important supportive role in spreading the use of leaf removal among California wine-grape growers. The active commitment of some farm advisors to the extension of leaf removal could be traced to their personal involvement in the two leaf-removal research projects. Both IPM canopy management projects utilized county-based farm advisors in determining research usefulness, in obtaining cooperators for field trials, in managing field trials and in collecting field trial data. This involvement seems to have encouraged a farm advisor interest and commitment that resulted in the active extension of leaf-removal strategies.

For their part, growers noted that education and external incentives may have encouraged their initial leaf-removal trials, but production-scale use would not have followed if the strategy had not improved grape production and economic management of their vineyards. All key informants agreed - growers have adopted leaf removal because it works.

\section{Impact on pesticide use}

The numbers of pesticide applications per season were established through interviews with key informants. The numbers varied by year and by growing region. Despite geographic and seasonal extremes,

\begin{tabular}{|c|c|c|}
\hline $\begin{array}{c}\text { Acr } \\
\text { in }\end{array}$ & $\begin{array}{l}\text { eage plantec } \\
\text { susceptible }\end{array}$ & $\begin{array}{l}\text { Estimated } \\
\text { acreage }\end{array}$ \\
\hline Growing region & varieties & under leaf removal \\
\hline North Coast & 57,193 & 28,596 \\
\hline San Joaquin Valley & 149,862 & 14,986 \\
\hline Central Coast & 36,709 & 7,341 \\
\hline Statewide total & 243,764 & 50,923 \\
\hline
\end{tabular}

TABLE 2. Estimated annual pesticide reduction due to leaf removal

\begin{tabular}{lc}
\hline \hline Pesticide & Reduction \\
\hline Fungicides & units per year \\
Benlate (50 WP) & $25,461 \mathrm{lb}$ \\
Captan (50 WP) & $50,923 \mathrm{lb}$ \\
Insecticides & \\
Dimethoate (25 WP) & $1,512,769 \mathrm{lb}$ \\
Thiodan (3 EC) & $9,548 \mathrm{gal}$ \\
\hline
\end{tabular}

TABLE 3. Bunch rot susceptible wine-grape varieties* $^{*}$

\begin{tabular}{ll}
\hline Barbera & Petite Sirah \\
Carignane & Pinot blanc \\
Chardonnay & Pinot Noir \\
Chenin blanc & Sauvignon blanc \\
French Colombard & Semillon \\
Gamay & Sylvaner \\
Gray Riesling & White Riesling \\
Grenache & Zinfandel
\end{tabular}

*From Grape Pest Management, UC Cooperative Extension Publication No. 4105. the consensus among most growers and farm advisors was that before canopy management at least two fungicide applications for control of bunch rots and two insecticide applications for control of leafhoppers were used each season in a typical vineyard management scheme. All interviewed growers and farm advisors agreed that leaf removal reduced the pesticide applications by a minimum of $50 \%$.

Estimates for rates of application were based on the lowest manufacturer recommendations found on pesticide labels. Pesticide choices were consistent across geographic regions. For control of both Botrytis and summer rot, most growers used benomyl or captan. For leafhopper management, growers used thiodan, a restricted use insecticide, and dimethoate. Farm advisors reported growers to be divided in their use of specific fungicides and insecticides, with some growers alternating between the two fungicides and insecticides from season to season. Based on this response, a decision of $50 \%$ use for each of the pesticides was incorporated into the pesticide reduction estimate.

Results provide conservative estimates. of yearly pesticide reduction trends in California resulting from use of leaf removal in wine-grape production (table 2). These results reflect a $50 \%$ reduction in the number of fungicide and insecticide applications required each growing season under a leaf-removal management strategy. These estimates are based on pesticide amounts used at recommended rates of product application. They do not include application rate reductions due to more efficient pesticide spray penetration possible on grapevines managed with leaf removal. Actual amounts of active ingredients in each pesticide are substantially less than product application rates.

\section{Discussion}

This case study was designed to answer three questions: 1) Are California growers using leaf-removal strategies refined by UCIPM research? 2) What factors have contributed to the field implementation of the research-based strategies? 3) What has been the impact of leaf removal on pesticide use? Answers to the first and third questions provide initial evidence that research on leaf removal in wine grapes has been widely implemented on a production scale and have directly led to a statewide reduction in pesticide use. The answer to the second question is that growers use leaf removal because (1) wineries and farm advisors encouraged it, (2) it is compatible with current vineyard management practices, (3) it is not overly complex or risky and (4) it effectively controls multiple pests.

Through the contract system for harvested fruit, wineries have a substantial in- fluence on vineyard management practices. Virtually all California wine-grape acreage is managed under winery contract. It is considered risky for growers to harvest their fruit independent of the price guarantees provided by the contract system. Emphasizing evidence of leaf-removal impact on wine-grape flavor, winery-provided education and incentives were the primary factors in encouraging grower trials of leaf removal. While the extent of processor influence on growing practices cannot be generalized across commodities or even across years within the same commodity, the case of leaf removal makes clear that commodity processors play a critical role in the field implementation of applied research. In light of this influence, commodity processors and brokers should be considered as partners in extension efforts.

Active involvement of county-based farm advisors in the canopy management research process increased the effectiveness of extension efforts. Growers and winery representatives commonly cited the importance of farm advisor support in their decisions to convert to a leaf-removal management strategy. All interviewed farm advisors noted their active involvement in the leaf-removal research projects helped increase their practical understanding of canopy management and their commitment to extend its field use. This case study provides evidence that active farm advisor participation in the research process increases the effectiveness of extension efforts in promoting field use of such research. As one advisor stated: "The bottom line is that my extension efforts primarily follow the research I do. Whatever I'm working on is what I want to talk about." An earlier review of IPM research showed that $45 \%$ of all funded projects were developed with farm advisor assistance, while experimental field trials were managed by farm advisors in $38 \%$ of all projects.

Through their direct and indirect contact with over two-thirds of California's wine-grape acreage, the key wine industry informants selected for interview in this study served as reliable sources to provide an estimate of the general trends in statewide use and impact of leaf removal and to identify the factors that contributed to its widespread field use. While this review describes conditions specific to canopy management research in the wine-grape industry, conclusions may have general value for the design, funding and implementation of any applied agricultural research with field use as its goal.

R. A. Pence is Postgraduate Researcher and J. I. Grieshop is Specialist, Department of Applied Behavioral Sciences, UC Davis. 